\title{
Üniversite Öğrencilerinin Çevresel Yaklaşımlarını Ölçmeye Yönelik Bir Araştırma: Manisa Celal Bayar Üniversitesi Örneği
}

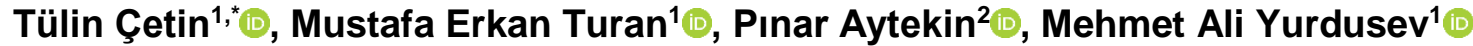

${ }^{1}$ Manisa Celal Bayar Üniversitesi, Mühendislik Fakültesi, Inşaat Mühendisliği Bölümü, 45140, Manisa.

2izmir Demokrasi Üniversitesi, İktisadi ve İdari Bilimler Fakültesi, İşletme Bölümü, 35140, İzmir.

\section{Özet}

Sanayinin ilerlemesi ve teknolojik gelișmeler sonucunda insanoğlu küresel çevre sorunları ile karșı karșıya kalmıștır. Çevre kirliliği sonucunda doğanın dengesi bozulurken bazı canlı türleri yok olmuştur. Çevre sorunlarının ve etkilerinin yoğun olarak hissedilmeye başlanması ile birlikte, insanların çevreye karşı tutumlarının belirlenmesi de önem kazanmaya başlamıştır. Çevresel tutumların belirlenmesi amacıyla 15 maddeden oluşan "Yeni Ekolojik Paradigma (New Ecological Paradigm-NEP)" ölçeği literatürde yaygın olarak kullanılmaktadır. Bu çalışmada da üniversite öğrencilerinin çevreye yönelik tutumlarını NEP ölçeği ile belirlemek ve bu tutumların ögrencilerin demografik, ekonomik, spor yapma, sigara kullanma, çevre dostu ürün tüketme, tasarruf yapma ve çevreyle ilgili bir derneğe üye olma gibi özellikleri arasındaki ilişkinin belirlenmesi amaçlanmıştır. Araştırmanın hedef grubu, Manisa Celal Bayar Üniversitesinde okuyan öğrencilerdir. Araștırmada hazırlanan anket, üniversitede okuyan öğrenciler arasında kolayda örnekleme yöntemi ile seçilen toplam 420 kişiye uygulanmıştır. Kullanılan ölçekten "insanllğın üstünlüğü", "çevresel felaket”, "doğanin üstünlüğü”, "teknolojik üstünlük” olarak isimlendirilen dört faktör elde edilmiştir. Ölçekten elde edilen dört faktöre ilişkin demografik özellikler açısından farklıllkları analiz edebilmek ve spor yapma, sigara kullanma, çevre dostu ürün tüketme, tasarruf yapma, çevreyle ilgili derneğe üye olma gibi etkenler arasındaki ilişkileri ortaya koymak amactyla hipotezler geliştirilmiştir. Bunun sonucunda geliştirilen hipotezlerden 18 tanesinde anlamlı bir ilişki olduğu belirlenmiștir.

\section{Anahtar Sözcükler}

Çevre, Çevresel Yaklaşım, Yeni Çevresel Paradigma Ölçeği

\section{A Research to Determine Environmental Approaches of University Students: Manisa Celal Bayar University Case}

\begin{abstract}
It is observed that technological developments have resulted in several global environmental problems. The balance of the nature has been destroyed and some species has been died out because of such environmental problems. As the environmental problems and their effects have been felt intensively, the determination of people's attitudes towards environment are of greater importance than ever before. New Ecological Paradigm (NEP) scale is widely used in the literature to determine environmental attitudes of the people. In this study, it is aimed to determine the attitudes of university students towards environment using the NEP scale and to determine the relationship between these attitudes and several characteristics of the students such as demography, economic situation, sport activity engaged, smoking, eco-friendly product consumption, saving and membership of an environmental association. The target group of the study is the students of Manisa Celal Bayar University. The questionnaire prepared in the study was applied to a total of 420 students selected by the sampling method among the students studying at the university. From the scale used, four factors called "supremacy of humanity", "environmental disaster", "supremacy of nature", "technological superiority" were obtained and then several hypotheses have been developed to analyze the differences in terms of demographical properties of the respondents with respect to the factors mentioned. The hypotheses developed also serve for establishing relationships among the parameters such as sport activity engaged, smoking, eco-friendly product consumption, saving and membership of an environmental association. As a result, it is found that there is significant relationship in 18 of the hypotheses developed.
\end{abstract}

$\underline{\text { Keywords }}$

Environment, Ecological Approach, New Ecological Paradigm Scale

\section{Giriş}

İnsanoğlunun yaşadığı gelişimin sonuçlarından biri de çevre sorunları olmuştur. Çevre sorunları başlangıçta sanayinin geliştiği bölgelerde görülmüş, ancak daha sonra küreselleşmiştir. Dolayısıyla tüm canlıları ilgilendiren bir konu haline gelmiştir. 
Çevre kirliği sonucunda doğal denge bozulmuş, bazı canlı türleri yok olmuş, son zamanlarda etkisi iyice hissedilmeye başlayan küresel ısınma ve sonucunda iklim değişikliği ortaya çıkmıştır. Çevre sorunları, gelinen noktada tüm canlıları tehdit etmektedir.

İnsanların farklı tutumlarının ve davranışlarının çevreye olumsuz etkisi çevre sorunlarının temelini oluşturmaktadır (Capra 2009). Dünyanın dolayısıyla yeni nesillerin geleceği çevre sorunlarının çözümünde yatmaktadır. Sorunun çözümü açısından bu tutumların ve davranışların çevreye zarar vermeyecek hale getirilmesi için tutum ve davranışların etkileyen faktörlerin araştırılması ve aralarındaki ilişkinin tanımlanması gerekmektedir. Elde edilen sonuçlar doğrultusunda yeni nesillerde çevre bilincini geliştirecek eğitimin her düzeyde verilmesi bir adım olarak düşünülebilir (Kılıç ve İnal 2010).

Çevresel tutumların belirlenmesi amacıyla 15 maddeden oluşan "Yeni Ekolojik Paradigma (New Ecological Paradigm-NEP)" ölçeği (Dunlap vd. 2000) literatürde yaygın olarak kullanılmaktadır. NEP (Dunlap ve Van Liere 1978; Dunlap vd. 2000; Dunlap, 2008) ilk olarak, Dunlap ve Van Liere tarafından 1978 yılında geliştirilmiş ve 2000 yılında gözden geçirilip yenilenmiştir. Literatür araştırmasında NEP'in çok farklı gruplara uygulandığı görülmektedir. Bu çalışmalardan özellikle öğrencilere yönelik olarak hazırlanan çalışmalar ve bazı diğer uygulamalar incelenmiştir. Rideout vd. (2005) çalışmalarında Ursinus College öğrencilerinin zamanla çevre ile ilgili tutumlarında bir değişme olup olmadığ1 ile ilgili yapılacak araştırmanın ilk etabını gerçekleştirmişlerdir. Farklı zamanlarda sistematik ve e-posta ile 5'li Likert tipi ölçek kullanılarak veri toplanmıştır. Günden ve Miran (2008) İzmir ili Torbalı ilçesinde bulunan çiftçilerin çevre tutumlarını belirlemek için NEP ölçeği kullanmışlardır. Yücel Işıldar (2008), Sağlık Hizmetleri Meslek Yüksek Okulu öğrencilerinin çevre ile ilgili almış oldukları derslerin çevreci yaklaşımlar geliştirmeleri üzerine bir etkisi olup olmadığını araştırmak amacıyla anketi yeni öğrencilere ve aynı öğrencilere mezun olurken uygulamıştır. Demirel vd. (2009) çevreye yönelik tutuma doğada yapılan rekreasyonel aktivitelerin etkisini incelemişlerdir. Örneklemi Ankara'da bulunan faklı üniversitelerin öğrencileri oluşturmaktadır. 5'li Likert tipi ölçek üzerinden değerlendirme yapılmıştır. Erdoğan (2009) farklı illerde bulunan dört üniversitenin öğrencileri üzerinde NEP ölçeğini denemiş ve öğrencilerin doğa merkezli veya insan merkezli düşünceye sahip olup olmadıklarını araştırmıştır. Alnıç̧ık ve Koç (2009) 5 farklı, Alnıaçık (2010) ise 7 farklı üniversitede okuyan öğrencilerin çevreye yönelik tutumları, NEP ölçeği kullanarak belirlenmiş ve üniversite öğrencilerinin çevre sorunlarına duyarlılık düzeyinin ortalamanın üzerinde olduğunu belirlemişlerdir. Sam vd. (2010) çalışmalarında üniversitede eğitim gören öğrencilerin çevresel tutumları ile benlik saygıları arasındaki ilişkiyi araştırmışlardır. Bu amaçla Yeni Çevresel Paradigma Ölçeği ve Benlik Saygısı Ölçeğini kullanarak anlamlı bir ilişki olduğunu ortaya koymuşlardır. Kılıç ve İnal (2010) yeni ekolojik paradigma ölçeği kullanarak üniversitede farklı bölümlerdeki öğrencilerin aldıkları eğitimlerinin çevreye yaklaşımlarını ve çevreci davranışlarını nasıl etkilediğini incelemişlerdir. Hawcroft ve Milfont (2010) son 30 yılda NEP kullanarak 36 farklı ülkede yapılan 69 farklı araştırmayı inceleyerek, NEP ölçeğinin kullanım farklılıklarını ve faktör sayılarını ortaya koymuşlardır. Harraway vd. (2012) ve Jowett vd. (2014) çalışmalarında öğrencilerin ekolojik dünya görüşlerinin aldıkları eğitimler sonucunda çevre merkezli hale gelip gelmediği ile ilgili karşılaştırma yapmak üzere NEP'i kullanmışlardır. Aytaç ve Öngen (2012), yeni çevresel paradigma ölçeğini kullanarak üniversitede eğitim gören öğrencilerin çevreye karşı tutumlarını doğrulayıcı faktör analizi ile analiz etmişlerdir. Sever ve Yalçınkaya (2012) sınıf öğretmenliği okuyan üniversite öğrencilerinin çevreye yönelik tutumlarını araştırmışlardır. Erkal vd. (2012) üniversitede çevre eğitimine yönelik bir ders alan veya almayan öğrencilerin çevresel tutumlarını yeni çevresel paradigma ölçeği ile incelemişlerdir. Turan vd. (2013) ortaöğretim öğrencilerinin almış oluğu biyoloji eğitiminin çevre etiği yaklaşımlarına ve eleştirel düşünmelerine olan etkilerini Yeni Çevresel Paradigma Ölçeği ve California Eleştirel Düşünme Eğilimi Ölçeğini kullanarak araştırmışlardır. Kılıç (2013) üniversite birinci ve son sınıflarda okuyan öğrencilerin, çevreci düşüncelerinin oluşmasında ve sonrasında da değişmesinde aldıkları çevre dersinin nasıl bir etkisi olduğunu NEP kullanarak incelemeyi amaçlamıştır. Hoşgör vd. (2015) iki farklı Sağlık Bilimleri Fakültesi'nde okuyan öğrencilerin çevreye yönelik tutumlarını NEP kullanarak kıyaslamışlardır. Sarıca ve Şahin (2015) Doğayla İlişkili Olma Ölçeğini Türkçe 'ye uyarlayarak ölçeğin ilk psikometrik özelliklerini incelemek ve doğayla ilişkili olma ve öz-aşkınlık arasındaki ilişki olup olmadığını saptamayı amaçlamışlardır. Bu amaçla üniversite öğrencilerine yönelik içinde NEP'in de bulunduğu bir çalışma gerçekleştirmişlerdir. Chang (2015) çalışmasında Çin'deki üniversite öğrencilerine NEP uygulayarak ekonomik önceliklerin ve teknolojiye olan bağlılığın çevreye kıyasla baskın hale geldiğini ortaya koymuştur. Davis ve Stroink (2016) üniversite öğrencilerinin çevresel yaklaşımlarını NEP kullanarak analiz etmişlerdir. Kroufek vd. (2016) ileride öğretmen olacak üniversite öğrencilerinin çevre ile ilgili davranışlarını, üniversite öncesi ve sonrası ile kıyaslama yapmak amacıyla araştırmışlardır.

Literatürde üniversite öğrencileri üzerine yapılan çalışmaların yanında farklı gruplar üzerinde de NEP'ten faydalanılan çalışmalar bulunmaktadır. Yıldırım ve Uğuz (2013), NEP ölçeği ile işletmelerin sürdürülebilir kalkınma sürecinde işletmelerin kurumsal sosyal sorumluluğunu araştırmışlardır. Fishman ve Smith (2017) çevresel kamu mallarının ve çevresel düşüncelerin ev fiyatları üzerine etkisi araştırırken NEP’ten faydalanmışlardır.

Literatür araştırmasından çıkarılacak sonuç olarak "Yeni Ekolojik Paradigma" ölçeği birçok alanda uygulanmış ve katılımcıların çevreye karşı tutumları belirlenmiştir. $\mathrm{Bu}$ çalışmada da üniversite öğrencilerinin çevreye yönelik tutumlarını NEP ölçeği ile belirlemek ve bu tutumların öğrencilerin demografik, ekonomik, spor yapma, sigara kullanma, çevre dostu ürün tüketme, tasarruf yapma ve çevreyle ilgili bir derneğe üye olma gibi özellikleri arasındaki ilişkinin belirlenmesi amaçlanmıştır. 


\section{Araştırmanın Yöntemi}

Araştırmanın ana kütlesini Manisa Celal Bayar Üniversitesi'nde okuyan tüm öğrenciler oluşturmaktadır. Manisa Celal Bayar Üniversitesi 2017-2018 öğrenci sayısı 55.473 kişidir. Sekaran (2003)'ın belli evrenleri temsil için kabul edebilecek örnek büyüklükleri tablosunda $\mathrm{N} \geq 50.000$ için $\mathrm{n}=382$ yeterli bir sayı olarak verilmiştir. Bu doğrultuda, kolayda örnekleme yöntemiyle seçilen 420 öğrenciye anket uygulanmış ve tüm anket yapılan tüm öğrencilerden yazılı onam formu alınmıştır. Tesadüfi olmayan örnekleme içerisinde en sık kullanılan yöntemlerden birisi kolayda örnekleme yöntemidir. $\mathrm{Bu}$ yöntemde, bilgi ve verilerin en kolay toplanabileceği bireyler örnek kapsamına alınır (Kurtuluş 2006). Anket formları uygulanmadan önce, Manisa Celal Bayar Üniversitesi Etik Kurulu'na başvurulmuş ve yazılı onay 23.05.2018 tarihinde yapılan 2018/03 sayılı toplantıda 3 sayılı kararla alınmıştır. Uygulanan 420 anket formunun 13'ü analize uygun olmadığından çıkarılmış, dolayısıyla 407 anket formu analize dahil edilmiştir. Örnek hacmi için gerekli büyüklük 407 adet kullanılabilir anket ile sağlanabilmektedir.

Anket formu, Dunlap vd. (2000) tarafından geliştirilen "Yeni Ekolojik Paradigma (New Ecological Paradigm-NEP)" ölçeğinden yararlanılarak hazırlanmıştır. Oluşturulan bu anket formunun ön testi için kolayda örnekleme yöntemiyle 40 öğrenci seçilmiş ve anket uygulanmıştır. Ankete gerekli düzeltmeler yapılarak son şekli verilmiştir. 11.12.201722.12.2017 tarihleri arasında anketler belirlenen örnekleme uygulanmıştır. Anket formu üç bölümden oluşmaktadır. Birinci bölümde, öğrencilerin çevreyle ilgili tutumlarını ölçmeye yönelik ifadelerin yer aldığı 15 maddelik NEP ölçeği kullanılmıştır. Öğrencilerin bu ifadelere katılım derecelerini belirlemek için, 5'li Likert ölçeği (1=Kesinlikle Katılmıyorum, 5=Kesinlikle Katılıyorum) kullanılmıştır. İkinci bölümde; öğrencilerin spor yapma, sigara kullanma, çevre dostu ürün tüketme, tasarruf yapma ve çevreyle ilgili derneğe üye olma gibi özelliklere yönelik maddelere yer verilmiştir. Bu bölümde dört seçenek sunulmuştur (1= Hiçbir zaman, 2= Ara sıra, 3=S1k sık, 4=Her zaman). Üçüncü bölümde ise; öğrencilerin demografik özelliklerini belirlemek amaciyla cinsiyet, anne ve babanın eğitim durumu ve mesleği, öğrencilerin kendi gelirleri ile ailelerinin gelirleri, yaşanan yer ve ev tipine iliş̧kin maddelere yer verilmiştir.

Güvenilirlik analizi (Cronbach's Alpha), ankette yer alan ifadelerin tutarlılığını ve ölçeğin güvenilirliğini ölçmek üzere uygulanacaktır. Daha sonra çevresel tutuma ilişkin değişkenleri bir araya toplayarak faktörlerin belirlenmesine amacıyla açıklayıcı faktör analizi yapılacaktır. Faktör analizinden, veriye faktör analizi uygulanıp uygulanmayacağını belirlemek için Kaiser-Meyer-Olkin (KMO) ve Barlett Testi'nden yapılacaktır. Bu testler sonucunda KMO değerinin $\% 60$ 'ın üstünde olması arzu edilmektedir (Nakip 2006).

\section{Araştırmanın Bulguları}

Ankete katılan öğrencilerin demografik özelliklerine göre dağılımları Tablo 1'de, aileleri ile ilgili demografik özelliklerine göre dağılımları Tablo 2'de, öğrencilerin diğer özelliklerine göre dağılımları ise Tablo 3'te görülmektedir. Tablo 1'de belirtildiği üzere anket yapılan öğrencilerin demografik özelliklerine göre \%45,5'inin "Kadın", \%54.5'inin ise "Erkek"; \%35,4'ünün aylık gelirlerinin 500 Türk Liras1 (TL)'den az olduğu, \%45,2'sinin 501-1000 TL arasında, \%14'ünün 1001-2000 TL arasında, \% 3,2'sinin 2001-3000 TL arasında, \%0,7'sinin 3001-4000 TL arasinda ve \%1,5'inin ise 4001 TL ve üzeri olduğu görülmektedir.

Ankete katılan öğrencilerinden elde edilen bilgiler ışı̆̆ında oluşturulan Tablo 2'de de belirtildiği üzere öğrencilerin ailelerinin demografik özelliklerine göre babalarının \%0,7'sinin okuryazar olmadığı, \%2,2'sinin okuryazar olduğu, \%13,3'ünün ilkokul, \%9,1'inin ortaokul, \%29,5'inin lise, \%38,3'ünün üniversite, $\% 6,9$ 'unun yüksek lisans / doktora mezunu olduğu; babalarının \%1'inin çalışmadığı, \%23,6'sının serbest meslek (muhasebeci, avukat, esnaf vb.) icra ettiği, $\% 13,5$ 'inin devlet memuru, $\% 13,5$ 'inin işçi, $\% 28,3$ 'ünün özel sektör çalışanı, $\% 20,1$ 'inin ise emekli olduğu; annelerinin $\% 2$ 'sinin okuryazar olmadığı, \%3,2'sinin okuryazar olduğu, \%17,4'ünün ilkokul, \%13,3'ünün ortaokul, \%34,4'ünün lise, \%26'sının üniversite, \%3,7'sinin yüksek lisans / doktora mezunu olduğu; annelerinin \%44,7'sinin çalışmadığ $, \% 5,7$ 'sinin serbest meslek (muhasebeci, avukat, esnaf vb.) icra ettiği, \%15,2'inin devlet memuru, \%4,9'unun işçi, \%17,9'unun özel sektör çalışanı, \%11,5'inin ise emekli olduğu; \%0,7'sinin aylık gelirlerinin 500,- TL'den az olduğu, \%2,7'sinin 5011000,- TL arasinda, \%9,6'sinın 1001-2000,- TL arasinda, \% 22,6'sinın 2001-3000,- TL arasinda, \%28,7'sinin 30014000,- TL arasında ve \%35,6'sının ise 4001,- TL'nin üzerinde olduğu; ailelerin \%5,4'ünün köyde, \%6,6'ssnın beldede, $\% 27$ 'sinin ilçe merkezinde, \%60,9'unun ise il merkezinde yaşadığı; ailelerin \%22,6'sının müstakil evde otururken, $\% 77,4$ 'ünün ise apartman dairesinde oturduğu görülmektedir.

Tablo 1: Araştırmaya Katılan Öğrencilerin Demografik Özelliklerine Göre Dağııımı

\begin{tabular}{|l|l|c|c|}
\hline \multicolumn{2}{|c|}{ Değişken } & Frekans & \% \\
\hline \multirow{4}{*}{ Cinsiyet } & Kadın & 185 & 45,5 \\
\cline { 2 - 4 } & Erkek & 222 & 54,5 \\
\hline \multirow{4}{*}{ Öğrencinin aylık geliri } & $500 \mathrm{TL}$ 'den az & 144 & 35,4 \\
\cline { 2 - 4 } & $501-1.000 \mathrm{TL}$ & 184 & 45,2 \\
\cline { 2 - 4 } & $1.001-2.000 \mathrm{TL}$ & 57 & 14,0 \\
\cline { 2 - 4 } & $2.001-3.000 \mathrm{TL}$ & 13 & 3,2 \\
\cline { 2 - 4 } & $3.001-4.000 \mathrm{TL}$ & 3 & 0,7 \\
\cline { 2 - 4 } & $4.001 \mathrm{TL}$ ve üzeri & 6 & 1,5 \\
\hline
\end{tabular}


Tablo 2: Araştırmaya Katılan Öğrencilerin Ailelerinin Demografik Özelliklerine Göre Dağılımı

\begin{tabular}{|c|c|c|c|}
\hline \multicolumn{2}{|r|}{ Değişken } & Frekans & $\%$ \\
\hline \multirow{7}{*}{ Babanın eğitim durumu } & Okuryazar değil & 3 & 0,7 \\
\hline & Okuryazar & 9 & 2,2 \\
\hline & İlkokul Mezunu & 54 & 13,3 \\
\hline & Orta Okul Mezunu & 37 & 9,1 \\
\hline & Lise Mezunu & 120 & 29,5 \\
\hline & Üniversite Mezunu & 156 & 38,3 \\
\hline & Yüksek Lisans / Doktora Mezunu & 28 & 6,9 \\
\hline \multirow{6}{*}{ Babanın mesleği } & Çalışmıyor & 4 & 1,0 \\
\hline & Serbest Meslek (Muhasebeci, Avukat, Esnaf vb.) & 96 & 23,6 \\
\hline & Devlet memuru & 55 & 13,5 \\
\hline & İşçi & 55 & 13,5 \\
\hline & Özel sektör çalışanı & 115 & 28,3 \\
\hline & Emekli & 82 & 20,1 \\
\hline \multirow{7}{*}{ Annenin eğitim durumu } & Okuryazar değil & 8 & 2,0 \\
\hline & Okuryazar & 13 & 3,2 \\
\hline & İlkokul Mezunu & 71 & 17,4 \\
\hline & Orta Okul Mezunu & 54 & 13,3 \\
\hline & Lise Mezunu & 140 & 34,4 \\
\hline & Üniversite Mezunu & 106 & 26,0 \\
\hline & Yüksek Lisans / Doktora Mezunu & 15 & 3,7 \\
\hline \multirow{6}{*}{ Annenin mesleği } & Çalışmıyor & 182 & 44,7 \\
\hline & Serbest Meslek (Muhasebeci, Avukat, Esnaf vb.) & 23 & 5,7 \\
\hline & Devlet memuru & 62 & 15,2 \\
\hline & İşçi & 20 & 4,9 \\
\hline & Özel sektör çalışanı & 73 & 17,9 \\
\hline & Emekli & 47 & 11,5 \\
\hline \multirow{6}{*}{ Ailenin aylık geliri } & 500 TL'den az & 3 & 0,7 \\
\hline & $501-1.000 \mathrm{TL}$ & 11 & 2,7 \\
\hline & $1.001-2.000 \mathrm{TL}$ & 39 & 9,6 \\
\hline & $2.001-3.000 \mathrm{TL}$ & 92 & 22,6 \\
\hline & $3.001-4.000 \mathrm{TL}$ & 117 & 28,7 \\
\hline & 4.001 TL ve üzeri & 145 & 35,6 \\
\hline \multirow{4}{*}{ Ailenin yaşadığı yer } & Köy & 22 & 5,4 \\
\hline & Belde & 27 & 6,6 \\
\hline & İlçe Merkezi & 110 & 27,0 \\
\hline & İl Merkezi & 248 & 60,9 \\
\hline \multirow{2}{*}{ Aile Evi Tipi } & Müstakil Ev & 92 & 22,6 \\
\hline & Apartman Dairesi & 315 & 77,4 \\
\hline
\end{tabular}

Tablo 3: Araştırmaya Katılan Öğrencilerin Diğer Özelliklerine Göre Dağılımı

\begin{tabular}{|c|c|c|c|}
\hline \multicolumn{2}{|l|}{ Değişken } & Frekans & $\%$ \\
\hline \multirow{4}{*}{ Spor yapma } & Hiçbir zaman & 36 & 8,8 \\
\hline & Ara sira & 244 & 60 \\
\hline & Sik sik & 83 & 20,4 \\
\hline & Her zaman & 44 & 10,8 \\
\hline \multirow{4}{*}{ Sigara içme } & Hiçbir zaman & 152 & 37,3 \\
\hline & Ara sira & 107 & 26,3 \\
\hline & Sik sik & 98 & 24,1 \\
\hline & Her zaman & 50 & 12,3 \\
\hline \multirow{4}{*}{ Çevre dostu (yeşil) ürünler tüketme } & Hiçbir zaman & 51 & 12,5 \\
\hline & Ara sira & 205 & 50,4 \\
\hline & Sik sik & 107 & 26,3 \\
\hline & Her zaman & 44 & 10,8 \\
\hline \multirow{4}{*}{$\begin{array}{l}\text { Su, elektrik vb. kullanırken tasarruf } \\
\text { etmeye çalışmak }\end{array}$} & Hiçbir zaman & 15 & 3,7 \\
\hline & Ara sira & 162 & 39,8 \\
\hline & Sik sik & 145 & 35,6 \\
\hline & Her zaman & 85 & 20,9 \\
\hline \multirow{2}{*}{$\begin{array}{l}\text { Çevreyle ilgili herhangi bir dernek ya da } \\
\text { kuruluşa üye olmak }\end{array}$} & Evet & 34 & 8,4 \\
\hline & Hayır & 373 & 91,6 \\
\hline
\end{tabular}

Tablo 3'te belirtildiği üzere anket yapılan öğrencilerin \%8,8'i hiç spor yapmazken \%10,8'inin her zaman spor yaptı̆ğ, \%60'ının ise ara sıra spor yaptığı, \%20,4'ünün sık sık spor yaptığı; \%37,3’ü hiç sigara içmemişken, \%12,3’ünün her zaman sigara içtiği, \%26,3'ünü ara sıra \%24,1'inin ise sık sık sigara içtiği; \%12,5'u hiçbir zaman çevre dostu (yeşil) ürünler tüketmediği, \% 10,8'inin her zaman tükettiği, \%50,4'ünün ara sıra \%26,3'ünün ise sık sık çevre dostu (yeşil) ürünler tükettiği; \%3,7'sinin hiçbir zaman su, elektrik vs. kullanırken tasarruf etmeye çalışmadığı, \%20,9'unun her zaman 
tasarrufa dikkat ettiği, \%39,8'inin ara sıra \%35,6'sının ise sık sık tasarruf etmeye çalıştığı; \%8,4'ünün çevreyle ilgili herhangi bir dernek veya kuruluşa üye olurken \%91,6'sının üye olmadığı görülmektedir.

Uygulanan güvenilirlik analizi sonucunda güvenilirlik katsayısı Cronbach's Alpha değeri 0,602 olarak bulunmuştur. Bu sonuç, ölçeğin oldukça güvenilir bir ölçek olduğunu göstermektedir (Kalayc1, 2010). Elde edilen güvenilirlik katsayısı değeri Türkçe NEP ölçeği ile üniversite öğrencilerine yönelik yapılan diğer çalışmalarla karşılaştırıldığında (Günden ve Miran 2008, $\alpha=0,62$; Iş1ldar 2008, $\alpha=0,62$; Erdoğan 2009, $\alpha=0.58$; Sam vd. 2009, $\alpha=0.66$; K1lıç ve İnal 2010, $\alpha=0.69$; Aytaç ve Öngen 2012, $\alpha=0.53$; Erkal vd. 2012, $\alpha=0.754$; Yıldırım ve Uğuz 2013, $\alpha=0.874$; Turan vd. 2013, $\alpha=0.86$; Kılıç 2013, $\alpha=0.63$ ) benzer değerler elde edildiği görülmüştür. Bu sonuçlardan sonra, açıklayıcı faktör analizi çevresel yaklaşıma ilişkin değişkenleri bir araya toplayarak faktörlerin belirlenmesi için uygulanmıştır. Faktör analizi yapmadan önce ise veri setinin faktör analizi için uygun olup olmadığının belirlenmesi için KMO ve Barlett Testi yapılmıştır. Buna göre; \% 95 güven aralığında KMO değeri, faktör analizi sonucunda 0,71>0,60 olarak elde edilmiştir (Bartlett = 927,000; df: $91 ; \mathrm{p}<0.000)$. Bu sonuçlar doğrultusunda veri setine faktör analizi yapılmıştır. Faktör analizin yapılırken varimaks rotasyonu kullanılmıştır. Dönüşümlü faktör yüklerinden faydalanılarak faktörlerdeki maddelerin taşıdıkları anlam dikkate alınmış ve literatür doğrultusunda 4 faktörlü analizler (Erdoğan 2009, Turan vd. 2013, Jowet vd. 2014) göz önünde bulundurularak elde edilen boyutlara sırasıyla; "insanlığın üstünlüğü”, “çevresel felaket”, “doğanın üstünlüğü”, “teknolojik üstünlük” isimleri verilmiştir. Faktör analizi sonuçlarına ilişkin bilgiler Tablo 4'te görülmektedir.

Verilere Kolmogorov-Smirnov Testi uygulanarak normal dağılıma uygunluğu araştırılmış, test sonucunda anlamlılık değerleri 0,05 'den küçük çıktığı için verilerin normal dağılmadığı sonucuna ulaşılmıştır. Bu nedenle hipotezlerin test edilmesinde parametrik olmayan testler kullanılmıştır. Bu doğrultuda, iki değişken arasında anlamlı bir ilişki olup olmadığını belirlemek için Spearman Sıra Korelasyonu kullanılmıştır. Değişkenlerin tam değerlerinin kullanılmadığı durumlarda elde bulunan veriler vasıflarına göre sayılarla sıralanabilmektedir. Değişkenler bu şekilde sıralanmışsa Spearman Sıra korelasyonu kullanılabilmektedir. Aralıksız ölçülen iki bağımsız grup arasındaki farklılıkları test etmek için Mann-Whitney U Testi kullanılmıştır. Bu test, grupların medyanlarını karşılaştırmaktadır. İki grup (cinsiyet vb.) arasındaki sıralamanın farklı olup olmadığını değerlendirmek için sürekli değişkenlerin, iki grup içerisinde, değerlerini sıralı hale dönüştürmektedir. Ayrıca, sürekli değişkenlere sahip üç ya da daha fazla grup (gelir, meslek vb.) arasındaki farklılıkları ortaya koymak için Kruskal-Wallis H Testi kullanılmıştır. Bu testte de değerler sıralı hale çevrilmekte ve her grup için sıralı ortalamalar karşılaştırılmaktadır (Kalaycı 2010).

Faktör analiziyle elde edilen bu dört faktöre ilişkin demografik özellikler açısından farklılıkları analiz edebilmek ve spor yapma, sigara kullanma, çevre dostu ürün tüketme, tasarruf yapma, çevreyle ilgili derneğe üye olma gibi etkenler arasındaki ilişkileri ortaya koymak amacıyla hipotezler geliştirilmiştir. Aşağıda sırasıyla, kurulan hipotezler ve bu hipotezler doğrultusunda yapılan analizlerin sonuçları yer almaktadır.

- $\mathrm{H}_{1}$ : Öğrencilerin İnsanlığın Üstünlüğüne ilişkin tutumları cinsiyetlerine göre istatistiki açıdan anlamlı bir farklılık göstermektedir.

- $\mathrm{H}_{2}$ : Öğrencilerin Çevresel Felakete ilişkin tutumları cinsiyetlerine göre istatistiki açıdan anlamlı bir farklılık göstermektedir.

- $\mathrm{H}_{3}$ : Öğrencilerin Doğanın Üstünlüğüne ilişkin tutumları cinsiyetlerine göre istatistiki açıdan anlamlı bir farklılık göstermektedir.

- $\mathrm{H}_{4}$ : Öğrencilerin Teknolojik Üstünlüğe ilişkin tutumları cinsiyetlerine göre istatistiki açıdan anlamlı bir farklılık göstermektedir.

Tablo 4: Faktör Analizi Sonuçları $(n=407)$

\begin{tabular}{|c|c|c|c|}
\hline FAKTÖRLER & $\begin{array}{c}\text { Faktör } \\
\text { Yükleri }\end{array}$ & $\begin{array}{c}\text { Açıklanan } \\
\text { Varyans (\%) }\end{array}$ & $\begin{array}{c}\text { Cronbach's } \\
\text { Alpha }\end{array}$ \\
\hline 1. Faktör: İnsanlığın Üstünlüğü & & 16,030 & 0,777 \\
\hline 12. İnsanlar doğaya hükmetmek için yaratılmışlardır. & 0,814 & & \\
\hline 10. İnsanlığın karşı karşıya kaldığı iddia edilen "ekolojik kriz" çok abartılmaktadır. & 0,805 & & \\
\hline 2. İnsanlar, ihtiyaçlarını karşılamak için doğal çevrede değişiklik yapma hakkına sahiptir. & 0,802 & & \\
\hline 2. Faktör: Çevresel Felaket & & 13,119 & 0,424 \\
\hline 13. Doğanın dengesi çok hassastır ve kolayca bozulabilmektedir. & 0,738 & & \\
\hline 15. Bugünkü durum aynı șekilde devam ederse yakında büyük bir ekolojik felaket yaşanacaktır. & 0,579 & & \\
\hline 11. Dünya, çok sınırlı yeri ve kaynağı olan bir uzay gemisine benzemektedir. & 0,562 & & \\
\hline 3. Faktör: Doğanın Üstünlüğü & & 12,266 & 0,433 \\
\hline 9. Özel yeteneklerine rağmen insanoğlu hala doğanın kurallarına bağımlıdır. & 0,716 & & \\
\hline 7. Bitki ve hayvanların da insanlar kadar yaşama hakkı vardır. & 0,668 & & \\
\hline 5. İnsanlar çevreye çok fazla zarar vermektedir. & 0,519 & & \\
\hline 4. Faktör: Teknolojik Üstünlük & & 11,492 & 0,501 \\
\hline 14. İnsanlar doğayı kontrol edebilmek için eninde sonunda onun nasıl çalıştığını öğreneceklerdir. & 0,777 & & \\
\hline 4. İnsan zekâsı dünyanın yaşanmaz bir hal almasını engelleyecektir. & 0,742 & & \\
\hline 8. Doğa, modern sanayileşmiș ulusların olumsuz etkileriyle mücadele edecek kadar güçlüdür. & 0,528 & & \\
\hline
\end{tabular}


- $\mathrm{H} 2_{1}$ : Öğrencilerin İnsanlığın Üstünlüğüne ilişkin tutumları aylık gelirlerine göre istatistiki açıdan anlamlı bir farklilık göstermektedir.

- $\mathrm{H} 2_{2}$ : Öğrencilerin Çevresel Felakete ilişkin tutumları aylık gelirlerine göre istatistiki açıdan anlamlı bir farklılık göstermektedir.

- $\mathrm{H} 2_{3}$ : Öğrencilerin Doğanın Üstünlüğüne ilişkin tutumları aylık gelirlerine göre istatistiki açıdan anlamlı bir farklılık göstermektedir.

- H24: Öğrencilerin Teknolojik Üstünlüğe ilişkin tutumları aylık gelirlerine göre istatistiki açıdan anlamlı bir farklıl1k göstermektedir.

- $\mathrm{H}_{1}$ : Öğrencilerin İnsanlığın Üstünlüğüne ilişkin tutumları ailelerinin aylık gelirine göre istatistiki açıdan anlamlı bir farkl1lık göstermektedir.

- $\mathrm{H}_{2}$ : Öğrencilerin Çevresel Felakete ilişkin tutumları ailelerinin aylık gelirine göre istatistiki açıdan anlamlı bir farklılık göstermektedir.

- $\mathrm{H} 3_{3}$ : Öğrencilerin Doğanın Üstünlüğüne ilişkin tutumları ailelerinin ailenin aylık gelirine göre istatistiki açıdan anlamlı bir farklılık göstermektedir.

- $\mathrm{H} 34_{4}$ : Öğrencilerin Teknolojik Üstünlüğe ilişkin tutumları ailelerinin aylık gelirine göre istatistiki açıdan anlamlı bir farkl1lık göstermektedir.

- $\mathrm{H} 4_{1}$ : Öğrencilerin İnsanlığın Üstünlüğüne ilişkin tutumları babanın eğitim durumuna göre istatistiki açıdan anlamlı bir farkl1lık göstermektedir.

- $\mathrm{H}_{2}$ : Öğrencilerin Çevresel Felakete ilişkin tutumları babanın eğitim durumuna göre istatistiki açıdan anlamlı bir farklılık göstermektedir.

- $\mathrm{H} 4_{3}$ : Öğrencilerin Doğanın Üstünlüğüne ilişkin tutumları babanın eğitim durumuna göre istatistiki açıdan anlamlı bir farkl1lık göstermektedir.

- $\mathrm{H} 4_{4}$ : Öğrencilerin Teknolojik Üstünlüğe ilişkin tutumları babanın eğitim durumuna göre istatistiki açıdan anlamlı bir farkl1lık göstermektedir.

- H51: Öğrencilerin İnsanlığın Üstünlüğüne ilişkin tutumları annenin eğitim durumuna göre istatistiki açıdan anlamlı bir farkl1lık göstermektedir.

- $\mathrm{H} 5_{2}$ : Öğrencilerin Çevresel Felakete ilişkin tutumları annenin eğitim durumuna göre istatistiki açıdan anlamlı bir farkl1lık göstermektedir.

- $\mathrm{H} 5_{3}$ : Öğrencilerin Doğanın Üstünlüğüne ilişkin tutumları annenin eğitim durumuna göre istatistiki açıdan anlamlı bir farkl1lık göstermektedir.

- H54: Öğrencilerin Teknolojik Üstünlüğe ilişkin tutumları annenin eğitim durumuna göre istatistiki açıdan anlamlı bir farkll1lk göstermektedir.

- $\mathrm{H6}_{1}$ : Öğrencilerin İnsanlığın Üstünlüğüne ilişkin tutumları babanın mesleğine göre istatistiki açıdan anlamlı bir farklıllk göstermektedir.

- $\mathrm{H6}_{2}$ : Öğrencilerin Çevresel Felakete ilişkin tutumları babanın mesleğine göre istatistiki açıdan anlamlı bir farklılık göstermektedir.

- $\mathrm{H6}_{3}$ : Öğrencilerin Doğanın Üstünlüğüne ilişkin tutumları babanın mesleğine göre istatistiki açıdan anlamlı bir farklılık göstermektedir.

- H6: Öğrencilerin Teknolojik Üstünlüğe ilişkin tutumları babanın mesleğine göre istatistiki açıdan anlamlı bir farklılık göstermektedir.

- $\mathrm{H}_{1}$ : Öğrencilerin İnsanlığın Üstünlüğüne ilişkin tutumları annenin mesleğine göre istatistiki açıdan anlamlı bir farklılık göstermektedir.

- $\mathrm{H7}_{2}$ : Öğrencilerin Çevresel Felakete ilişkin tutumları annenin mesleğine göre istatistiki açıdan anlamlı bir farklılık göstermektedir.

- $\mathrm{H7}_{3}$ : Öğrencilerin Doğanın Üstünlüğüne ilişkin tutumları annenin mesleğine göre istatistiki açıdan anlamlı bir farklılık göstermektedir.

- $\mathrm{H7}_{4}$ : Öğrencilerin Teknolojik Üstünlüğe ilişkin tutumları annenin mesleğine göre istatistiki açıdan anlamlı bir farkl11lk göstermektedir.

- $\mathrm{H}_{1}$ : Öğrencilerin İnsanlığın Üstünlüğüne ilişkin tutumları ailelerinin yaşadığı yere göre istatistiki açıdan anlamlı bir farkl1lık göstermektedir.

- H82: Öğrencilerin Çevresel Felakete ilişkin tutumları ailelerinin yaşadığı yere göre istatistiki açıdan anlamlı bir farklılık göstermektedir.

- $\mathrm{H}_{3}$ : Öğrencilerin Doğanın Üstünlüğüne ilişkin tutumları ailelerinin yaşadığı yere göre istatistiki açıdan anlamlı bir farkl1lık göstermektedir.

- H84: Öğrencilerin Teknolojik Üstünlüğe ilişsin tutumları ailelerinin yaşadığı yere göre istatistiki açıdan anlamlı bir farkl1lık göstermektedir.

- H91: Öğrencilerin İnsanlığın Üstünlüğüne ilişkin tutumları yaşadıkları evin tipine göre istatistiki açıdan anlamlı bir farkl11ık göstermektedir. 
- $\mathrm{H}_{2}$ : Öğrencilerin Çevresel Felakete ilişkin tutumları yaşadıkları evin tipine göre istatistiki açıdan anlamlı bir farklılık göstermektedir.

- $\mathrm{H}_{3}$ : Öğrencilerin Doğanın Üstünlüğüne ilişkin tutumları yaşadıkları evin tipine göre istatistiki açıdan anlamlı bir farklılı göstermektedir.

- $\mathrm{H9}_{4}$ : Öğrencilerin Teknolojik Üstünlüğe ilişkin tutumları yaşadıkları evin tipine göre istatistiki açıdan anlamlı bir farklılık göstermektedir.

- H10 bir ilişki vardır.

- $\mathrm{H} 10_{2}$ : Öğrencilerin Çevresel Felakete ilişkin tutumları ile spor yapma arasında istatistiki açıdan anlamlı bir ilişki vardir.

- $\mathrm{H} 10_{3}$ : Öğrencilerin Doğanın Üstünlüğüne ilişkin tutumları ile spor yapma arasında istatistiki açıdan anlamlı bir iliş̧ki vardır.

- H104: Öğrencilerin Teknolojik Üstünlüğe ilişkin tutumları ile spor yapma arasında istatistiki açıdan anlamlı bir ilişki vardır.

- H11 1 : Öğrencilerin İnsanlığın Üstünlüğüne ilişkin tutumları ile sigara içmeleri arasında istatistiki açıdan anlamlı bir ilişski vardır.

- H11 $1_{2}$ Öğrencilerin Çevresel Felakete ilişkin tutumları ile sigara içmeleri arasında istatistiki açıdan anlamlı bir ilişki vardır.

- H11 ilişki vardır.

- H114: Öğrencilerin Teknolojik Üstünlüğe ilişkin tutumları ile sigara içmeleri arasında istatistiki açıdan anlamlı bir iliş̧i vardır.

- H121: Öğrencilerin İnsanlığın Üstünlüğüne ilişkin tutumları ile çevre dostu (yeşil) ürünler tüketme arasında istatistiki açıdan anlamlı bir ilişki vardır.

- H122: Öğrencilerin Çevresel Felakete ilişkin tutumları ile çevre dostu (yeşil) ürünler tüketme arasında istatistiki açıdan anlamlı bir ilişki vardır.

- H12 $2_{3}$ Öğrencilerin Doğanın Üstünlüğüne ilişkin tutumları ile çevre dostu (yeşil) ürünler tüketme arasında istatistiki açıdan anlamlı bir ilişki vardır.

- H124: Öğrencilerin Teknolojik Üstünlüğe ilişkin tutumları ile çevre dostu (yeşil) ürünler tüketme arasında istatistiki açıdan anlamlı bir ilişki vardır.

- H13 çalışmak arasında istatistiki açıdan anlamlı bir ilişki vardır.

- H13 $3_{2}$ : Öğrencilerin Çevresel Felakete ilişkin tutumları ile su, elektrik vb. kullanırken tasarruf etmeye çalışmak arasında istatistiki açıdan anlamlı bir ilişki vardır.

- H133: Öğrencilerin Doğanın Üstünlüğüne ilişkin tutumları ile su, elektrik vb. kullanırken tasarruf etmeye çalışmak arasında istatistiki açıdan anlamlı bir ilişki vardır.

- H134: Öğrencilerin Teknolojik Üstünlüğe ilişkin tutumları ile su, elektrik vb. kullanırken tasarruf etmeye çalışmak arasında istatistiki açıdan anlamlı bir ilişki vardır.

- $\mathrm{H} 14_{1}$ : Öğrencilerin İnsanlığın Üstünlüğüne ilişkin tutumları ile çevreyle ilgili herhangi bir dernek ya da kuruluşa üye olmak arasında istatistiki açıdan anlamlı bir ilişki vardır.

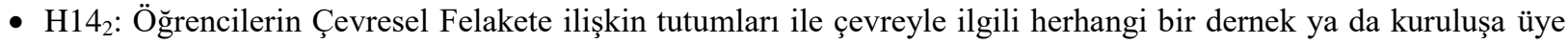
olmak arasında istatistiki açıdan anlamlı bir ilişki vardır.

- $\mathrm{H} 14_{3}$ : Öğrencilerin Doğanın Üstünlüğüne ilişsin tutumları ile çevreyle ilgili herhangi bir dernek ya da kuruluşa üye olmak arasında istatistiki açıdan anlamlı bir ilişki vardır.

- $\mathrm{H} 14_{4}$ : Öğrencilerin Teknolojik Üstünlüğe ilişkin tutumları ile çevreyle ilgili herhangi bir dernek ya da kuruluşa üye olmak arasında istatistiki açıdan anlamlı bir ilişki vardır.

Tablo 5'te yer alan sonuçlara göre, öğrencilerin çevresel felakete ve teknolojik üstünlüğe ilişkin tutumları cinsiyete göre anlamlı bir farklılık göstermektedir $(\mathrm{p}<0,05)$. Bu durumda $\mathrm{H}_{2}$ ve $\mathrm{H}_{4}$ hipotezleri kabul edilmiștir. Tablo 5 'te de görüleceği gibi, erkek öğrencilerin çevresel felaket olasılığı fikrine daha yakın oldukları ve kadın öğrencilere göre daha fazla önem verdikleri görülmektedir. Teknolojik üstünlük açısından bakıldığında ise kadın öğrencilerin konuya daha fazla önem verdikleri anlaşılmaktadır.

Tablo 6'daki sonuçlar incelendiğinde $\mathrm{H} 2_{1}$ hipotezinin kabul edildiği görülmektedir ( $\left.\mathrm{p}<0,05\right)$. Öğrencilerin insanlığın üstünlüğüne ilişkin tutumları aylık gelirlerine göre farklılık göstermektedir. 501-1.000 TL gelire sahip olan öğrencilerin insanlığın üstünlüğüne daha fazla inandığı anlaşılmaktadır.

Tablo 7 incelendiğinde, $\mathrm{H} 3_{1}$ hipotezinin kabul edildiği görülmektedir $(\mathrm{p}<0,05)$. Buna göre, öğrencilerin insanlı̆̆ın üstünlüğüne ilişkin tutumları ailelerinin aylık gelirlerine göre farklılık göstermektedir. Aileleri 4.001 TL ve üzeri gelire sahip olan öğrencilerin insanlığın üstünlüğ̈̈ne daha fazla inandığı anlaşılmaktadır. 
Tablo 5: Faktörler Açısından Öğrencilerin Cinsiyetlerine Göre Farklııkları Gösteren Mann Whitney U Testi Sonuçları

\begin{tabular}{|c|c|c|c|c|c|c|c|c|c|}
\hline \multirow[b]{3}{*}{ Cinsiyet } & \multirow[b]{3}{*}{$\mathrm{N}$} & \multicolumn{8}{|c|}{ Faktörler } \\
\hline & & \multicolumn{2}{|c|}{ İnsanlığın Üstünlüğü } & \multicolumn{2}{|c|}{ Çevresel Felaket } & \multicolumn{2}{|c|}{ Doğanın Üstünlüğü } & \multicolumn{2}{|c|}{ Teknolojik Üstünlük } \\
\hline & & Sira Ortalaması & $\mathbf{p}$ & $\begin{array}{c}\text { Sira } \\
\text { Ortalamas1 }\end{array}$ & $\mathbf{p}$ & $\begin{array}{c}\text { Sira } \\
\text { Ortalamas1 }\end{array}$ & p & Sira Ortalaması & $\mathbf{p}$ \\
\hline Kadın & 183 & 202,87 & \multirow{2}{*}{0,984} & 189,29 & \multirow{2}{*}{0,030} & 205,26 & \multirow{2}{*}{0,716} & 216,72 & \multirow{2}{*}{0,031} \\
\hline Erkek & 222 & 203,11 & & 214,30 & & 201,14 & & 191,69 & \\
\hline
\end{tabular}

Tablo 6: Faktörler Açısından Öğrencilerin Aylık Gelirlerine Göre Farklııkları Gösteren Kruskal-Wallis H Testi Sonuçları

\begin{tabular}{|c|c|c|c|c|c|c|}
\hline \multirow[b]{3}{*}{ Öğrencinin Geliri } & \multirow[b]{3}{*}{$\mathrm{N}$} & & \multicolumn{4}{|c|}{ Faktörler } \\
\hline & & & $\begin{array}{l}\text { İnsanlığın } \\
\text { Üstünlüğü }\end{array}$ & $\begin{array}{l}\text { Çevresel } \\
\text { Felaket }\end{array}$ & $\begin{array}{c}\text { Doğanın } \\
\text { Üstünlüğü }\end{array}$ & $\begin{array}{c}\text { Teknolojik } \\
\text { Üstünlük }\end{array}$ \\
\hline & & $\mathbf{p}$ & 0,002 & 0,436 & 0,169 & 0,410 \\
\hline 500 TL'den az & 144 & \multirow{6}{*}{ 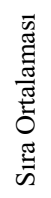 } & 175,91 & 203,94 & 195,77 & 203,50 \\
\hline $501-1.000 \mathrm{TL}$ & 184 & & 229,95 & 207,25 & 218,93 & 199,58 \\
\hline $1.001-2.000 \mathrm{TL}$ & 57 & & 186,50 & 180,69 & 178,36 & 230,58 \\
\hline $2.001-3.000 \mathrm{TL}$ & 13 & & 224,96 & 239,23 & 215,00 & 164,08 \\
\hline $3.001-4.000 \mathrm{TL}$ & 3 & & 208,00 & 274,83 & 144,17 & 167,17 \\
\hline 4.001 TL ve üzeri & 6 & & 201,25 & 215,42 & 193,42 & 203,83 \\
\hline
\end{tabular}

Tablo 7: Faktörler Açısından Öğrencilerin Ailelerinin Aylık Gelirlerine Göre Farklılıkları Gösteren Kruskal-Wallis H Testi Sonuçları

\begin{tabular}{|c|c|c|c|c|c|c|}
\hline \multirow[b]{3}{*}{ Ailenin Geliri } & \multirow[b]{3}{*}{$\mathrm{N}$} & & \multicolumn{4}{|c|}{ Faktörler } \\
\hline & & & $\begin{array}{l}\text { İnsanlığın } \\
\text { Üstünlüğü }\end{array}$ & $\begin{array}{l}\text { Çevresel } \\
\text { Felaket }\end{array}$ & $\begin{array}{c}\text { Doğanın } \\
\text { Üstünlüğü }\end{array}$ & $\begin{array}{c}\text { Teknolojik } \\
\text { Üstünlük }\end{array}$ \\
\hline & & p & 0,000 & 0,328 & 0,381 & 0,137 \\
\hline 500 TL'den az & 3 & \multirow{6}{*}{ 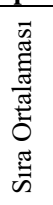 } & 76,67 & 322,83 & 117,83 & 301,00 \\
\hline $501-1.000 \mathrm{TL}$ & 11 & & 86,36 & 197,32 & 208,77 & 218,73 \\
\hline $1.001-2.000 \mathrm{TL}$ & 39 & & 132,64 & 193,83 & 174,05 & 235,67 \\
\hline $2.001-3.000 \mathrm{TL}$ & 92 & & 172,22 & 188,69 & 213,04 & 213,09 \\
\hline $3.001-4.000 \mathrm{TL}$ & 117 & & 205,13 & 210,74 & 209,68 & 201,98 \\
\hline 4.001 TL ve üzeri & 145 & & 254,01 & 209,06 & 203,16 & 188,22 \\
\hline
\end{tabular}

Tablo 8'deki sonuçlara göre; $\mathrm{H} 4_{1}, \mathrm{H} 5_{1}, \mathrm{H} 5_{4}$ hipotezleri kabul edilmiştir (p<0,05). Öğrencilerin insanlığın üstünlüğüne ilişkin tutumlarının anne ve babalarının eğitim düzeylerine göre farklılık gösterdiği görülmektedir. Öğrencilerin babalarının eğitim düzeyleri arttıkça, öğrencilerin insanların üstünlüğü fikrine daha fazla inandıkları görülmektedir. Benzer durum öğrencilerin annelerinin eğitim durumlarına göre de karşımıza çıkmaktadır. Öğrencilerin annelerinin eğitim düzeyleri arttıkça, öğrencilerin insanlığın üstünlüğü fikrine daha fazla inandıkları görülmektedir. Ayrıca öğrencilerin teknolojik üstünlüğüne ilişkin tutumları annelerinin eğitim düzeylerine göre farklılık göstermektedir. Öğrencilerin annelerinin eğitim düzeyleri düştükçe, öğrencilerin teknolojik üstünlüğe daha fazla inandıkları görülmektedir.

Tablo 8: Faktörler Açısından Öğrencilerin Babalarının ve Annelerinin Eğitim Durumlarına Göre Farklııkları Gösteren Kruskal-Wallis H Testi Sonuçları

\begin{tabular}{|c|c|c|c|c|c|c|}
\hline \multirow[b]{3}{*}{ Babanın Eğitimi } & \multirow[b]{3}{*}{$\mathrm{N}$} & & \multicolumn{4}{|c|}{ Faktörler } \\
\hline & & & $\begin{array}{l}\text { İnsanlığın } \\
\text { Üstünlüğ̈̈ }\end{array}$ & $\begin{array}{l}\text { Çevresel } \\
\text { Felaket }\end{array}$ & $\begin{array}{c}\text { Doğanın } \\
\text { Üstünlüğü }\end{array}$ & $\begin{array}{c}\text { Teknolojik } \\
\text { Üstünlük }\end{array}$ \\
\hline & & $\mathbf{p}$ & 0,000 & 0,375 & 0,586 & 0,092 \\
\hline Okuryazar değil & 3 & \multirow{7}{*}{ 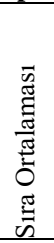 } & 23,50 & 133,67 & 89,00 & 194,00 \\
\hline Okuryazar & 9 & & 91,11 & 151,39 & 176,89 & 187,83 \\
\hline İlkokul Mezunu & 54 & & 130,04 & 211,79 & 202,89 & 210,47 \\
\hline Orta Okul Mezunu & 37 & & 136,09 & 207,34 & 192,15 & 241,31 \\
\hline Lise Mezunu & 120 & & 187,70 & 189,76 & 202,58 & 214,71 \\
\hline Üniversite Mezunu & 156 & & 256,85 & 214,37 & 210,21 & 182,82 \\
\hline Yüksek Lisans / Doktora Mezunu & 28 & & 267,39 & 212,30 & 214,36 & 220,57 \\
\hline Annenin Eğitimi & $\mathrm{N}$ & $\mathbf{p}$ & 0,000 & 0,126 & 0,147 & 0,023 \\
\hline Okuryazar değil & 8 & & 90,69 & 193,31 & 161,44 & 285,69 \\
\hline Okuryazar & 13 & $\vec{\Xi}$ & 141,12 & 161,04 & 133,31 & 232,81 \\
\hline İlkokul Mezunu & 71 & 壱 & 141,51 & 212,53 & 187,65 & 233,73 \\
\hline Orta Okul Mezunu & 54 & 莺 & 154,31 & 166,23 & 204,54 & 203,40 \\
\hline Lise Mezunu & 140 & $\overbrace{}^{2}$ & 213,92 & 211,87 & 216,10 & 198,26 \\
\hline Üniversite Mezunu & 106 & $\stackrel{\pi}{=}$ & 262,77 & 208,67 & 210,65 & 190,26 \\
\hline Yüksek Lisans / Doktora Mezunu & 15 & & 285,63 & 236,13 & 203,50 & 147,57 \\
\hline
\end{tabular}


Tablo 9'daki sonuçlar; H6 $1, \mathrm{H6}_{2}, \mathrm{H7}{ }_{1}$ hipotezlerinin kabul edildiğini göstermektedir (p<0,05). Öğrencilerin anne ve babalarının meslekleri açısından bakıldığında, insanlığın üstünlüğüne ilişkin tutumları farklılık göstermektedir. Özel sektör çalışanı babaları olan öğrencilerin ve işçi olarak çalışan annesi olan öğrencilerin insanların üstünlüğü fikrine daha fazla inandığı görülmektedir. Ayrıca öğrencilerin çevresel felakete ilişkin tutumlarının babalarının mesleklerine göre farklılık gösterdiği görülmektedir. Babası çalışmayan öğrencilerin çevresel felakete daha fazla inandıkları görülmektedir.

Tablo 10'daki sonuçlara göre, $\mathrm{H} 8_{1}$ ve $\mathrm{H} 8_{3}$ hipotezleri kabul edilmiştir $(\mathrm{p}<0,05)$. Buna göre, öğrencilerin insanlı̆̆ın üstünlüğüne ve doğanın üstünlüğüne ilişkin tutumlarının ailelerinin yaşadığı yere göre farklılık göstermektedir. Ailesi il merkezinde yaşayan öğrencilerin, insanların üstünlüğü fikrine daha fazla inandıkları görülmektedir.

Tablo 11'de yer alana sonuçlara göre; H9 hipotezi kabul edilmiştir. Öğrencilerin insanlığın üstünlüğüne ilişkin tutumlarının ailelerinin yaşadığı ev tipine göre farklılık gösterdiği görülmektedir. Ailesi apartman dairesinde yaşayan öğrencilerin, insanların üstünlüğü fikrine daha fazla inandıkları görülmektedir.

Tablo 12'deki sonuçlar incelendiğinde; $\mathrm{H} 10_{1}, \mathrm{H} 11_{4}, \mathrm{H} 12_{2}, \mathrm{H} 12_{4}, \mathrm{H} 13_{4}$ hipotezlerinin kabul edildiği görülmektedir. Spor yapan öğrenciler açısından bakıldığında, spor yapma ile insanlığın üstünlüğü fikri arasında istatistiki açıdan anlamlı bir ilişki olduğu görülmektedir. Öğrencilerin sigara içmesi ile teknolojik üstünlüğe ilişkin tutumları arasında istatistiki açıdan anlamlı fakat negatif yönlü bir ilişki olduğu anlaşılmaktadır.

Öğrencilerin çevre dostu (yeşil) ürün kullanımları ile çevresel felakete ilişkin tutumları arasında istatistiki açıdan anlamlı fakat negatif yönlü bir ilişki olduğu görülmektedir. Negatif yönlü bu ilişkiden, öğrencilerin yeşil ürün kullanımı ile çevresel felaketlerin azalabileceğini düşündükleri anlaşılabilmektedir. Çevre dostu (yeşil) ürün kullanımı ile teknolojik üstünlüğe ilişkin tutumlar arasındaki ilişkiye bakıldığında ise, istatistiki açıdan anlamlı ve pozitif yönlü bir ilişki olduğu görülmektedir. Çevre dostu ürün kullanmaya eğilimli olan öğrencilerin bu ürünlerin üretilmesi açısından teknolojinin üstünlüğüne inandıklarını söylemek mümkündür. Su ve elektrik kullanırken tasarruf etmeye çalışmakla teknolojik üstünlük arasında istatistiki açıdan anlamlı bir ilişki olduğu görülmüştür. Bu durum, tasarruf işlemi için teknolojiden yararlanma gereksinimden kaynaklandığı şeklinde yorumlanabilir. Çevreyle ilgili herhangi bir dernek veya kuruluşa üyelik ile çevresel tutumlar arasında herhangi bir anlamlı ilişki bulunamamıştır. Bu duruma, öğrencilerin sadece \%8,4’ün çevreyle ilgili herhangi bir dernek veya kuruluşa üye olmasının etkisi olduğu düşünülmektedir.

Tablo 9 Faktörler Açısından Öğrencilerin Babalarının ve Annelerinin Mesleklerine Göre Farklııkları Gösteren KruskalWallis H Testi Sonuçları

\begin{tabular}{|c|c|c|c|c|c|c|}
\hline \multirow[b]{3}{*}{ Babanın Mesleği } & \multirow[b]{3}{*}{$\mathrm{N}$} & & \multicolumn{4}{|c|}{ Faktörler } \\
\hline & & & $\begin{array}{l}\text { İnsanlığın } \\
\text { Üstünlüğg̈ }\end{array}$ & $\begin{array}{c}\text { Çevresel } \\
\text { Felaket }\end{array}$ & $\begin{array}{c}\text { Doğanın } \\
\text { Üstünlüğü }\end{array}$ & $\begin{array}{c}\text { Teknolojik } \\
\text { Üstünlük }\end{array}$ \\
\hline & & $\mathbf{p}$ & 0,000 & 0,048 & 0,959 & 0,106 \\
\hline Çalışmıyor & 4 & \multirow{6}{*}{ 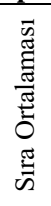 } & 77,25 & 260,25 & 162,50 & 255,38 \\
\hline Serbest Meslek & 96 & & 193,75 & 209,94 & 209,59 & 218,94 \\
\hline Devlet Memuru & 55 & & 191,18 & 175,27 & 197,82 & 223,85 \\
\hline İşçi & 55 & & 196,37 & 189,34 & 205,85 & 198,24 \\
\hline Özel Sektör Çalışanı & 115 & & 246,25 & 227,23 & 205,51 & 179,99 \\
\hline Emekli & 82 & & 176,65 & 190,82 & 200,26 & 208,23 \\
\hline Annenin Mesleği & $\mathrm{N}$ & $\mathbf{p}$ & 0,000 & 0,777 & 0,587 & 0,624 \\
\hline Çalışmıyor & 182 & $\vec{D}$ & 235,22 & 203,37 & 199,01 & 212,04 \\
\hline Serbest Meslek & 23 & 苂 & 259,67 & 223,76 & 191,43 & 197,41 \\
\hline Devlet Memuru & 62 & $\frac{\pi}{\pi}$ & 126,93 & 201,44 & 222,98 & 202,52 \\
\hline İşçi & 20 & 5 & 236,23 & 175,88 & 178,28 & 223,67 \\
\hline Özel Sektör Çalışanı & 73 & $\mathbb{\Xi}$ & 220,50 & 213,32 & 212,18 & 185,30 \\
\hline Emekli & 47 & $\bar{n}$ & 172,37 & 197,65 & 202,66 & 198,69 \\
\hline
\end{tabular}

Tablo 10: Faktörler Açısından Öğrencilerin Ailelerinin Yaşadığı Yere Göre Farklııkları Gösteren Kruskal-Wallis H Testi Sonuçları

\begin{tabular}{|c|c|c|c|c|c|c|}
\hline \multirow[b]{3}{*}{ Ailenin yaşadığı yer } & \multirow[b]{3}{*}{$\mathrm{N}$} & & \multicolumn{4}{|c|}{ Faktörler } \\
\hline & & & $\begin{array}{l}\text { İnsanlığın } \\
\text { Üstünlüğü }\end{array}$ & $\begin{array}{c}\text { Çevresel } \\
\text { Felaket }\end{array}$ & $\begin{array}{c}\text { Doğanın } \\
\text { Üstünlüğü }\end{array}$ & $\begin{array}{c}\text { Teknolojik } \\
\text { Üstünlük }\end{array}$ \\
\hline & & $\mathbf{p}$ & 0,002 & 0,290 & 0,044 & 0,203 \\
\hline Köy & 22 & $\vec{y}$ & 162,77 & 211,02 & 178,91 & 204,52 \\
\hline Belde & 27 & $\widetilde{\Xi}$ & 215,83 & 182,44 & 149,57 & 161,57 \\
\hline İlçe Merkezi & 110 & $\overline{\#} \frac{\pi}{\pi}$ & 174,48 & 220,27 & 209,77 & 215,25 \\
\hline İl Merkezi & 248 & & 219,46 & 198,51 & 209,59 & 203,58 \\
\hline
\end{tabular}


Tablo 11: Faktörler Açısından Öğrencilerin Ailelerinin Yaşadığı Ev Tipine Göre Farklııkları Gösteren Mann Whitney U Testi Sonuçları

\begin{tabular}{|c|c|c|c|c|c|c|c|c|c|}
\hline \multirow[b]{3}{*}{$\begin{array}{l}\text { Ailenin Yaşadığı } \\
\text { Ev Tipi }\end{array}$} & \multirow[b]{3}{*}{$\mathrm{N}$} & \multicolumn{8}{|c|}{ Faktörler } \\
\hline & & \multicolumn{2}{|c|}{ İnsanlığın Üstünlüğü } & \multicolumn{2}{|c|}{ Çevresel Felaket } & \multicolumn{2}{|c|}{ Doğanın Üstünlüğü } & \multicolumn{2}{|c|}{ Teknolojik Üstünlük } \\
\hline & & $\begin{array}{c}\text { Sira } \\
\text { Ortalamas }\end{array}$ & $\mathrm{p}$ & $\begin{array}{c}\text { Sira } \\
\text { Ortalamas } 1\end{array}$ & $\mathrm{p}$ & $\begin{array}{c}\text { Sira } \\
\text { Ortalamas }\end{array}$ & $\mathrm{p}$ & $\begin{array}{c}\text { Sira } \\
\text { Ortalamas1 }\end{array}$ & $\mathrm{p}$ \\
\hline Müstakil Ev & 92 & 179,31 & \multirow{2}{*}{0,053} & 202,91 & \multirow{2}{*}{0,918} & 183,78 & \multirow{2}{*}{0,053} & 209,89 & \multirow{2}{*}{0,582} \\
\hline Apartman Dairesi & 315 & 211,21 & & 204,32 & & 209,90 & & 202,28 & \\
\hline
\end{tabular}

Tablo 12: Faktörler ve Öğrencilerin Diğer Özellikleri Arasındaki Illişkileri Gösteren Spearman Korelasyon Analizi Sonuçları

\begin{tabular}{|c|c|c|c|c|c|}
\hline & & \multicolumn{4}{|c|}{ Faktörler } \\
\hline & & İnsanlığın Üstünlüğü & Çevresel Felaket & Doğanın Üstünlüğü & Teknolojik Üstünlük \\
\hline Spor Yapma & \multirow{5}{*}{ 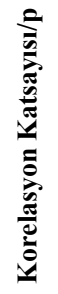 } & $0,130 * * / 0,009$ & $-0,065 / 0,193$ & $-0,011 / 0,831$ & $-0,028 / 0,569$ \\
\hline Sigara İçme & & $0,061 / 0,220$ & $0,089 / 0,073$ & $-0,005 / 0,920$ & $-0,158^{* * *} / 0,001$ \\
\hline $\begin{array}{l}\text { Çevre Dostu (Yeşil) Ürün } \\
\text { Kullanımı }\end{array}$ & & $-0,094 / 0,059$ & $-0,200 * * / 0,000$ & $-0,033 / 0,505$ & $0,129 * * / 0,009$ \\
\hline $\begin{array}{l}\text { Su, Elektrik vb. Kullanırken } \\
\text { Tasarruf Etme }\end{array}$ & & $0,062 / 0,213$ & $-0,075 / 0,131$ & $0,070 / 0,157$ & $0,121 * / 0,014$ \\
\hline $\begin{array}{l}\text { Çevreyle ilgili herhangi bir } \\
\text { dernek veya kuruluşa üyelik }\end{array}$ & & $-0,150 / 0,759$ & $0,043 / 0,386$ & $0,047 / 0,349$ & $-0,093 / 0,061$ \\
\hline
\end{tabular}

\section{Sonuç ve Öneriler}

Yapılan çalışmada; Manisa Celal Bayar Üniversitesi öğrencilerinin çevreye yönelik tutumları yeni çevresel paradigma ölçeği ile belirlenmiştir. Ölçekten “insanlığın üstünlüğü”, “çevresel felaket”, “doğanın üstünlüğü”, "teknolojik üstünlük” olarak isimlendirilen dört faktör elde edilmiştir. Çalışmanın diğer adımında ise elde edilen faktörler ile öğrencilerin demografik, ekonomik, spor yapma, sigara kullanma, çevre dostu ürün tüketme, tasarruf yapma ve çevreyle ilgili bir derneğe üye olma gibi özellikleri arasındaki ilişkiler için her bir faktör için 14'er hipotez belirlenmiştir.

Cinsiyetlerine göre öğrenciler incelendiğinde, erkek öğrencilerin çevresel felaket olasılı̆̆g fikrine daha yakın oldukları ve kadın öğrencilere göre daha fazla önem verdikleri görülmüştür. Teknolojik üstünlük açısından bakıldığında ise, kadın öğrencilerin konuya daha fazla önem verdikleri anlaşılmıştır. Bu konudaki diğer araştırmalar incelendiğinde bazı araştırmalarda cinsiyetin etkili olduğu anlaşılırken, bazılarında ise cinsiyetin etkisine rastlanmamıştır. Alnıçık (2010)'1n çalışmasında doğa merkezcilik açısından kadınlar erkeklere göre daha yüksek bir puan almıştır. Erkal vd. (2012) kadınların erkeklere göre çevreye yönelik daha olumlu tutum içerisinde olduklarını ortaya koymuştur. Sam vd. (2010) ise kadın öğrencilerin çevre merkezci yaklaşım ortalamasının erkek öğrencilere göre yüksek olduğunu tespit etmiştir. Chang (2015) az farkla da olsa kadın öğrencilerin çevreyi erkek öğrencilere göre daha fazla umursadıklarını ifade etmiştir. Hoşgör vd. (2015) kadın öğrencilerin ve ebelik öğrencilerinin çevreye yönelik duyarlılıklarını daha fazla bulmuştur. Yücel Işıldar (2008)'in çalışmasında ise cinsiyetin çevreci yaklaşım ve davranışlar üzerinde etkili bir değişken olmadığ 1 görülmüştür. Benzer şekilde Demirel vd. (2009)'in çalışmasında da cinsiyete göre çevreye yönelik tutumlar arasında anlamlı bir ilişki çıkmamıştır. Harraway vd. (2012) benzer çalışmalarda cinsiyetin ekolojik dünya görüşü açısından önemli bir belirleyici olduğunu belirtmiş, ancak çalışmalarını yürüttükleri farklı alanlarda eğitim gören öğrencilerde bazı gruplarda büyük çoğunluğun erkek olması nedeniyle çıkan sonuçlarının kıyaslama açısından iyi değerlendirilmesi gerekliliğine vurgu yapmışlardır. Sever ve Yalçınkaya (2012) öğretmen adaylarının cinsiyetlerinin gerek doğa merkezli gerekse insan merkezli çevresel tutumları üzerinde anlamlı bir etkiye sahip olmadığını bulmuşlardır.

Kendi aylık gelirlerine göre öğrenciler incelendiğinde, öğrencilerin insanlığın üstünlüğüne ilişkin tutumlarının aylık gelirlerine göre farklılık gösterdiği ve düşük gelirli öğrencilerin insanlığın üstünlüğüne daha fazla inandıkları anlaşılmıştır. Aileleri üst düzey gelire sahip olan öğrenciler ise insanlığın üstünlüğüne daha fazla inanmaktadırlar. Alnıaçık (2010)'a göre genel olarak aile gelirinin çevre dostu davranış üzerinde anlamlı bir etki yaratmadığını, düşük gelir grubundaki ailelere mensup öğrencilerin ise insan merkezciliğe daha fazla önem verdiklerini ortaya koymuştur. Erkal vd. (2012) gelir düzeyi 1500,- TL ve üzeri olanların daha düşük olanlara göre çevreye yönelik daha olumlu tutum içerisinde olduklarını ortaya koymuştur.

Öğrencilerin babalarının ve annelerinin eğitim düzeyleri arttıkça, öğrencilerin insanların üstünlüğü fikrine daha fazla inandıkları görülmüştür. Bununla birlikte, öğrencilerin annelerinin eğitim düzeyleri düştükçe, öğrencilerin teknolojik üstünlüğe daha fazla inandıkları belirlenmiştir. Benzer sonuca Rideout vd. (2005), Günden ve Miran (2008), Yücel Iş1ldar (2008), Alnıaçık ve Koç (2009), Alnıçcık (2010)'ın çalışmalarında da rastlanmıştır. Rideout vd. (2005)'e göre eğitim düzeyinde artış, çevresel sorunlara olan farkındalığı arttırmaktadır. Günden ve Miran (2008)'e göre çiftçilerin eğitim düzeylerindeki artışla çevre tutumlarında olumlu bir artış olduğu görülmüştür. Yücel Işıldar (2008), eğitim sürecinin çevreci yaklaşımların oluşması ve netleşmesinde anlamlı bir farklılık yarattığını ortaya koymuştur. 
Alnıaçık ve Koç (2009), üniversite eğitimi alan öğrencilerin dikkate değer düzeyde çevre duyarlılığı olduğunu belirlemiştir. Alnıaçık (2010) aile reisinin eğitim düzeyinin, öğrencilerin çevreci yönelim düzeyi üzerinde anlamlı bir etkisinin olmadığını belirtmiştir. Erkal vd. (2012) ise anne ve babası üniversite mezunu olanların olmayanlara göre çevreye yönelik daha olumlu tutum içerisinde olduklarını ortaya koymuştur.

Öğrencilerin anne ve babalarının meslekleri açısından bakıldığında, özel sektör çalışanı babaları olan öğrencilerin ve işçi olarak çalışan annesi olan öğrencilerin insanların üstünlüğü fikrine daha fazla inandıkları görülmüştür. Ayrıca babası çalışmayan öğrenciler, çevresel felakete daha fazla inanmaktadır.

Ailesi il merkezinde yaşayan öğrencilerin, insanların üstünlüğü fikrine daha fazla inandıkları belirlenmiştir. Benzer şekilde, ailesi apartman dairesinde yaşayan öğrencilerin, insanlığın üstünlüğü fikrine daha fazla inandıkları görülmüştür. Oysa Alnıaçık (2010) öğrencilerin ailesinin yaşadığı yerleşim yeri türünün, öğrencilerin çevreci yönelimi üzerinde anlamlı bir etkisinin olmadığını, ancak yerleşim yeri büyüdükçe (örneğin köyden büyük şehire doğru gidildikçe) çevreci dünya görüşünün düzeyinin de arttığını belirlemiştir. Demirel vd. (2009)'in çalışmasında ise öğrencilerin en uzun süre yaşadıkları yerleşim birimi ile çevreye yönelik duyarlılıkları arasında anlamlı bir ilişki çıkmamıştır.

Spor yapan öğrenciler açısından bakıldığında, spor yapma ile insanlığın üstünlüğü fikri arasında istatistiki açıdan anlamlı bir ilişki olduğu saptanmıştır. Öğrencilerin sigara içmesi ile teknolojik üstünlüğe ilişkin tutumları arasında negatif yönlü bir ilişki olduğu görülmüştür. Demirel vd. (2009)'in çalışmasında ise doğa sporları etkinliklerine katılım durumlarına göre çevreye yönelik tutumları arasında ise anlamlı bir ilişki bulunmamıştır.

Öğrencilerin çevre dostu (yeşil) ürün kullanımları ile çevresel felakete ilişkin tutumları arasında negatif yönlü bir ilişki olduğu görülmektedir. Negatif yönlü bu ilişkiden, öğrencilerin yeşil ürün kullanımı ile çevresel felaketlerin azalabileceğini düşündükleri anlaşılabilmektedir. Çevre dostu (yeşil) ürün kullanımı ile teknolojik üstünlüğe ilişkin tutumlar arasındaki ilişkiye bakıldığında ise, çevre dostu ürün kullanmaya eğilimli olan öğrencilerin bu ürünlerin üretilmesi açısından teknolojinin üstünlüğüne inandıklarını söylemek mümkündür.

$\mathrm{Su}$ ve elektrik kullanırken tasarruf etmeye çalışmakla teknolojik üstünlük arasında istatistiki açıdan anlamlı bir ilişki olduğu görülmüştür. Bu durumun, tasarruf işlemi için teknolojiden yararlanma gereksinimden kaynaklandığı söylenebilir.

Çevreyle ilgili herhangi bir dernek veya kuruluşa üyelik ile çevresel tutumlar arasında herhangi bir anlamlı ilişki bulunamamıştır. Bunda, öğrencilerin sadece \%8,4'ün çevreyle ilgili herhangi bir dernek veya kuruluşa üye olmasının etkisi olduğu düşünülmektedir. Daha kapsamlı bir araştırma elde edebilmek için çevre ile ilgili herhangi bir dernek veya kuruluşa üye olanlar arasında benzer bir araştırmanın yapılması önerilmektedir.

Üniversite öğrencilerinin çevreye karşı tutumları incelendiğinde; doğadan uzakta şehir merkezlerinde yaşayanların, ailelerinin artan gelir düzeylerine paralel olarak insan merkezci bir yaklaşım sergiledikleri anlaşılmaktadır. Çevre dostu ürün kullananlar ile su ve elektrikte tasarruf etmeye çalışanların teknolojinin üstünlüğüne inandıkları ve teknoloji yardımı ile çevreyi koruyabileceklerini düşündükleri ortaya çıkmaktadır.

$\mathrm{Bu}$ sonuçlara göre faktörler ile özellikler arasında belirlenen hipotezlerin toplam 18 tanesi kabul edilmiştir.

Elde edilen sonuçlar doğrultusunda incelediğimiz bazı faktörlerin öğrencilerin çevreye daha duyarlı bireyler haline gelmeleri konusunda etkili oldukları, bazı faktörlerin ise etkili olmadıkları görülmektedir. Etkili olan faktörlerin daha çok kişide değiştirilemeyecek demografik özellikler gibi olduğu anlaşılmaktadır. Benzer sonuçlar farklı araştırmacılar tarafından yapılan çalışmalarda da ortaya konmuştur (Alnıçık, 2010). Bu sebeple çevre konusunda öğrencilerde değişiklik yapabilmek için eğitim gibi farklı faktörlere önem verilmesi ve bu konuda araştırma yapılması önerilmektedir. Gelecek çalışma olarak; eğitim planlarında çevre konulu dersler ile ilgili yapılacak değişikliklerin etkisinin araştırılması planlanmaktadır. Bu amaçla, literatürdeki benzer çalışmalardaki gibi ilgili dersi içeren eğitim planına tabi öğrenciler ile tabi olmayan öğrencilerin kıyaslanması düşünülmektedir. Böylece öğrencilerin çevresel tutumlarında eğitimle meydana gelebilecek değişimlerin ölçülmesi hedeflenmektedir.

\section{Kaynakça}

Alnıaçık Ü., (2010), Çevreci Yönelim, Çevre Dostu Davranış Ve Demografik Özellikler: Üniversite Öğrencileri Üzerinde Bir Araştırma, SÜ İIBB Sosyal ve Ekonomik Araştırmalar Dergisi, 10(20), 507-532.

Alnıçık Ü., Koç, F., (2009), Yeni Çevresel Paradigma Ölçeği İle Üniversite Öğrencilerinin Çevreye Yönelik Tutumlarının Değerlendirilmesi, Balıkesir Üniversitesi Burhaniye MYO Bölgesel Kalkınma Kongresi, ss.178-185.

Aytaç M., Öngen, B., (2012), Doğrulayıcı Faktör Analizi İle Yeni Çevresel Paradigma Ölçeğinin Yapı Geçerliliğinin İncelenmesi, İstatistikçiler Dergisi, 5(2012), 14-22.

Capra F., (2009), Batı Düşüncesinde Dönüm Noktası, (Çevirmen Mustafa Armağan), İnsan Yayınları, İstanbul, 532ss.

Chang G., (2015), Materialist Value Orientations As Correlates of the New Ecological Paradigm Among University Students In China, Psychological Reports: Sociocultural Issues in Psychology, 116(2), 597-612.

Davis A.C., Stroink M.L., (2016), The Relationship between Systems Thinking and the New Ecological Paradigm, Systems Research and Behavioral Science, Syst. Res. 33(4), 575-586.

Demirel M., Gürbüz B., Karaküçük S., (2009), Rekreasyonel Aktivitelere Katılımın Çevreye Yönelik Tutum Üzerindeki Etkisi ve Yeni Ekolojik Paradigma Ölçeği'nin Geçerliği Ve Güvenirliği, Spormetre Beden Eğitimi Ve Spor Bilimleri Dergisi, VII(2), 47-50.

Dunlap R.E, Van Liere K.D., Mertig A. G., Jones R.E., (2000), Measuring Endorsement of the New Ecological Paradigm: A Revised NEP Scale, Journal of Social Issues, 56(3), 425-442.

Dunlap R.E., (2008), The New Environmental Paradigm Scale: From Marginality to Worldwide Use, The Journal of Environmental Education, 40(1), 3-18. 
Dunlap R.E., Van Liere K.D., (1978), The "New Environmental Paradigm": A Proposed Measuring Instrument and Preliminary Results, Journal of Environmental Education, 9(4), 10-19.

Erdoğan N., (2009), Testing the New Ecological Paradigm Scale: Turkish Case, African Journal of Agricultural Research, 4(10), 10231031.

Erkal S., Kılıç İ., Şahin H., (2012), Comparison of Environmental Attitudes of University Students Determined Via the New Environmental Paradigm Scale According to the Students' Personal Characteristics, Egitim Arastirmalari - Eurasian Journal of Educational Research, 49(49), 21-40.

Fishman J., Smith V.K., (2017), Latent Tastes, Incomplete Stratification, and the Plausibility of Vertical Sorting Models, Environ Resource Econ, 66(2), 339-361.

Günden C., Miran B., (2008), Yeni Çevresel Paradigma Ölçeğiyle Çiftçilerin Çevre Tutumunun Belirlenmesi: İzmir İli Torbalı İlçesi Örneği, Ekoloji, 18(69), 41-50.

Harraway J., Broughton-Ansin F., Deaker L., Jowett T., Shephard K., (2012), Exploring the Use of the Revised New Ecological Paradigm Scale (NEP) to Monitor the Development of Students' Ecological Worldviews, The Journal of Environmental Education, 43(3), 177-191.

Hawcroft L.J., Milfont T.L., (2010), The Use (and Abuse) of the New Environmental Paradigm Scale Over the Last 30 Years: A metaanalysis, Journal of Environmental Psychology 30(2), 143-158.

Hoşgör H., Gündüz Hoşgör D., Tosun N., (2015), Sağlık Bilimleri Fakültesi Öğrencilerinin Çevreye Yönelik Tutumlarının Belirlenmesi: Klyaslamalı Bir Analiz, HSP, 2(2), 198-207.

Jowett T., Harraway J., Lovelock B., Skeaff S., Slooten L., Strack M., Shephard K., (2014), Multinomial-Regression Modeling of the Environmental Attitudes of Higher Education Students Based on the Revised New Ecological Paradigm Scale, The Journal of Environmental Education, 45(1), 1-15.

Kalaycı Ş., (2010), SPSS Uygulamalı Çok Değişkenli İstatistik Teknikleri, 5. Baskı, Asil Yayın Dağıtım, Ankara, 426ss.

Kılıç S., (2013), Yükseköğretimde Çevre Eğitiminin Çevre Bilinci Oluşumuna Etkisi: Niğde Üniversitesi İ̈BF Kamu Yönetimi Örneği, Niğde Üniversitesi İ̈BF Dergisi, 6(1), 63-80.

K1lıç S., İnal M.E., (2010), Yüksek Öğretimde Çevre Ĕ̈itimi Alan Ve Almayan Öğrencilerde Çevre Bilinci: Niğde Üniversitesi Örneği, Niğde Üniversitesi İ̈BF Dergisi, 3(2), 70-83.

Kroufek R., Chytrý V., Janovec J., Čepičková I.B., (2016), The Use Of New Ecological Paradigm Scale Among Pre-Service Primary Teachers: Limits And Possibilities, IJAEDU- International E-Journal of Advances in Education, 2(4), pp.105-111.

Kurtuluş K., (2006), Pazarlama Araştırmaları, Genişletilmiş ve Gözden Geçirilmiş 8. Basım, Literatür Yayıncılık, İstanbul, 900ss.

Nakip M., (2006), Pazarlama Araştırmaları: Teknikler ve (SPSS Destekli) Uygulamalar, Genişletilmiş 2. Basım, Seçkin Yayıncılık, Ankara, 592ss.

Rideout B.E., Hushen K., McGinty D., Perkins S., Tate J., (2005), Endorsement of the New Ecological Paradigm in Systematic and Email Samples of College Students, The Journal of Environmental Education, 36(2), 15-23.

Sam N., Sam R., Öngen K.B., (2010), Üniversite Öğrencilerinin Çevresel Tutumlarının Yeni Çevresel Paradigma ve Benlik Saygısı Ölçeği İle Incelenmesi, Akademik Bakış Dergisi, 21, 1-16.

Sarıça H., Şahin S.H., (2015), Doğayla İlişkili Olma Ölçeğinin İlk Psikometrik Bulguları ve Öz-Aşkınlıkla İlişkisi, Uşak Üniversitesi Sosyal Bilimler Dergisi, 8(4), 267-280.

Sekaran U., (2003), Research Methods For Business: A Skill Building Approach, John Wiley \& Sons,Inc., USA, 464ss.

Sever R., Yalçınkaya E., (2012), Sinıf Öğretmeni Adaylarının Çevresel Tutumlarının İncelenmesi, Marmara Coğrafya Dergisi, 26,1 15.

Turan S., Aydın H., Uğurlu İ., (2013), Eleştirel Düşünme Becerilerini Temel Alan Biyoloji Eğitiminin Ortaöğretim Öğrencilerinin Ekolojik Etik Yaklaşımlarına Ve Eleştirel Düşünme Eğilimlerine Etkisi, NWSA-Education Sciences, 8(2), 232-244.

Yıldırım M.H., Uğuz Ş., (2013), Sürdürülebilir Kalkınma Sürecinde Kurumsal Sosyal Sorumluluğun Önemi: Aksaray Ilinde Bir Araştırma, Sosyal ve Beşeri Bilimler Dergisi, 5(2), 202-212.

Yücel Iş̧1dar G., (2008), Meslek Yüksekokulları Boyutunda "Çevre Eğitimi"nin Çevreci Yaklaşımlar ve Davranışlar Üzerindeki Etkilerinin Değerlendirilmesi, Türk Eğitim Bilimleri Dergisi, 6(4), 759-778. 